\title{
The proportionality of monetary policy as a macro-juristic theory
}

\author{
Lauris Bocs
}

Rīga Stradiņš University, Riga, Latvia

\begin{abstract}
The year 2018 marked the passing of 10 years for attempts of systemic financial instability prevention and according legal regulation reforms in the European Union. The role of monetary policy has increased up to the point that the European Central Bank has established so-called unconventional monetary policies, including unprecedented asset purchase programmes within the public and private debt sector of the EU. Therefore, the aim of the research is to determine the regulations and associated problems for the enforcement of EU law within the EU's financial sector for unified unconventional monetary policies and to give an assessment of possible solutions, especially in relation to the protection of property value. Using descriptive, logical and deductive methodology the paper concludes that monetary policy is a legislative act without the usual constitutional ex ante evaluation, especially for proportionality. Hence, a macro-juristic theory is described to limit the possible risks.
\end{abstract}

\section{Introduction}

From 2008 to 2018, the European Union (EU) developed several legal reforms to prevent future systemic risks in the financial sector. However, from 2015 to the end of 2018 the European Central Bank (ECB) pursued so-called unconventional measures for stimulating the economy, including asset purchase programmes (APP) such as the corporate sector purchase programme (CSPP), public sector purchase programme (PSPP), asset-backed securities purchase programme (ABSPP) and third covered bond purchase programme (CBPP3). It means that for 4 years the ECB participated mostly in the so-called secondary financial markets by buying up private and public financial assets such as bonds and other debt securities. That increased the asset amount of the ECB's balance sheet and provided financial equilibrium for market participants, for example, commercial banks due to them having a steady market demand and allowing stabilizing the capital amount of their balance sheets. This is generally called quantitative easing $(\mathrm{QE})$, which is the way to stimulate inflation [1]. As this is an unprecedented occurrence in EU policy, the paper evaluates the initial macroeconomic context for the field of law. Afterwards the mechanisms are described within a comprehensive theoretical framework for mitigating risks for disproportionate risks for money's purchasing power as the right to property.

The aim of the research is to determine the normative regulations and associated problems for the enforcement of EU law within the EU's financial sector for unified unconventional monetary policies and to give an assessment of possible solutions, especially in relation to protection capabilities of property value within the EU. The author will address the published 
paper in a video commentary. It will also be recorded and made available as an audio article for listening ${ }^{1}$ with a Creative Commons license ${ }^{2}$.

Implementing the aim with descriptive, logical and deductive methodology within a doctrinal and legal anthropology analysis, the normative supervision of EU property protection is evaluated for its legal merits with relation to a justification of a macro level hypothesis. Namely, that such monetary policy is a legislative act without the usual constitutional ex ante evaluation, especially for proportionality. Recommendations, therefore, are made for the resolution of the possible problems. According to thought experiment deductions and scenario modelling within the research, the unified monetary policy results can be achieved within a comprehensive framework according to member state judicial constitutional mechanisms with the inclusion of already established monetary policy legislators, i.e., central banks.

\section{Relation between EU monetary policy and property rights}

Article 132 of the Treaty on the Functioning of the EU states the legal rights of the ECB and central banks of the member states. It allows monetary policy of central banks to be a form of delegated power of the sovereign's legislative branch [2]. The governing council of the ECB uses this delegated legislative power in the form of decisions establishing also the legal framework for EU wide unconventional monetary policies such as buying member state debt securities, which means increasing the debt of the government of an EU member state [3]. Overall these actions fall within the QE, which is intended to improve the general liquidity of financial market participants to allow more economic activity and increase the inflation rate close to $2 \%$ per year [4]. For legal scholars this means that the established legislation describes a loss of money's purchasing power of $2 \%$ annually as the main goal.

In an international jurisdiction, the sovereignty of member states becomes increasingly unclear. Monetary considerations are some of the major debates for several considerations relating to classical monetary sovereignty. As described by international law scholar and economist Claus Zimmermann, the transfer of far-reaching sovereign powers to a monetary union, instead of provoking the erosion of the monetary sovereignty of the participating states, may have to be regarded as the most effective form of cooperative sovereignty [5]. However, there are more than just legal aspects to such assumptions. As has been noted by philosopher Jürgen Habermas, a joint economic government inevitably calls for more than just mere financial sector operations, because it is strongly related to national budgets. Thus, it intervenes with the budgetary privileges of national legislators [6]. The author agrees with that statement due to the increasing blur between fiscal independence and international monetary obligations. Hence, the judicial concept of cooperative sovereignty can be considered still in its infancy. That allows this article to investigate fundamental considerations such as the effective protection of property rights in an ever more integrated Economic and Monetary Union of the EU.

Article 17 of the Charter of Fundamental Rights of the EU describes the right to property as, inter alia, the right to own and use lawfully acquired possessions without deprivation, except in the public interest [7]. There is no definitive legal doctrine for comparisons between Article 17 and the delegated competencies of the ECB. However, the author's previous works, published during his doctoral studies, have already shown that purchasing power of money

\footnotetext{
${ }^{1}$ List of public files by Lauris Bočs. Available from: http://files.fm/laurisbocs [visited 10.02.2019.].

2 Creative Commons license CC BY 4.0. Available from: http://creativecommons.org/licenses/by/4.0/ [viewed10.02.2019.].
} 
has all necessary attributes to be considered a property right of those who possess it. It means that the intended loss of purchasing power would have to be evaluated regarding the legitimate aim, need and proportionality from the viewpoint of public interest [8]. Accordingly, the further macroeconomic evaluation of monetary policies within legal research could develop a congruent planning mechanism for future policies.

The importance of the aforementioned stems forms the indications that a future consolidation of capital markets is already an established political priority with the aim of ensuring safe financial assets and their transactions [9]. It should be noted that at the time of writing no legal analysis, reports or judicial case materials exist for any effects or impact assessments. It is due to this fact, that this paper bases its analysis on the macroeconomic reports, as well as applicable legal concepts for not just current, but also de lege ferenda, i.e., future macroeconomic and monetary policies. The main concern is to evaluate, whether the ingrained constitutional procedures for property right limitation within EU democratic societies matches the ones currently in use for monetary policy.

\section{Procedural legal issues in EU monetary policy}

The basic issues relating to unconventional monetary policy deal with several aspects of EU member state budgets and fiscal discipline. For one, member state budgets depend on balancing income and expenditures to adjust budget deficits and government debt according to political obligations such as the so-called Maastricht criteria [10]. This means that every EU member state has at least political restrictions on how much liabilities it can take up.

Secondly, government spending is related to sustainable income management and only the crucial deficits ought to be covered by borrowing on open markets from private partners. This in case of the unconventional ECB policies has been essentially substituted by a public authority, causing also questions of lawfulness by at least the German constitutional court about the ability of the ECB and central banks to finance EU member states [11]. The last and arguably final preliminary ruling of the European Court of Justice about the ECB's QE program in the end of 2018 dismissed any hypothetical variability. It stated that since the ECB does not purchase government debt securities in a fixed amount and directly from states but from other market participants, who cannot be sure of the amount the ECB will buy, the QE program does fall within the monetary policy rights of EU central banks. It ensures also that governments still have to maintain sound budgetary policies [12]. It is worth mentioning that there have not been any court cases relating to the other QE programs, so with these couple of court cases the ECB's unconventional monetary policies have been confirmed as being the exclusive competence of the monetary policy legislator, i.e., central banks.

The aforementioned means that, for instance, government debt of an EU member state can be indirectly financed by newly created central bank money. Yet, as the updated government debt percentages show (Fig. 1) EU government debt is at a level that on average already exceeds the $60 \%$ government debt ceiling of the so-called Maastricht Criteria. That means that a considerable number of states explicitly do not oblige the political and legal intentions stated for EU-wide macroeconomic stability.

As is also evident from the QE statistical data (Fig. 2), the programmes have essentially allowed public and private borrowers to increase their balance sheets overall reaching almost three trillion euro. This means that the leveraged debt ratio increases almost exponentially due to the original source of the liquidity and the receiver of freshly created liquidity. Mainly, the ECB and accordingly member states who try to finance their debt obligations from the financial markets. 


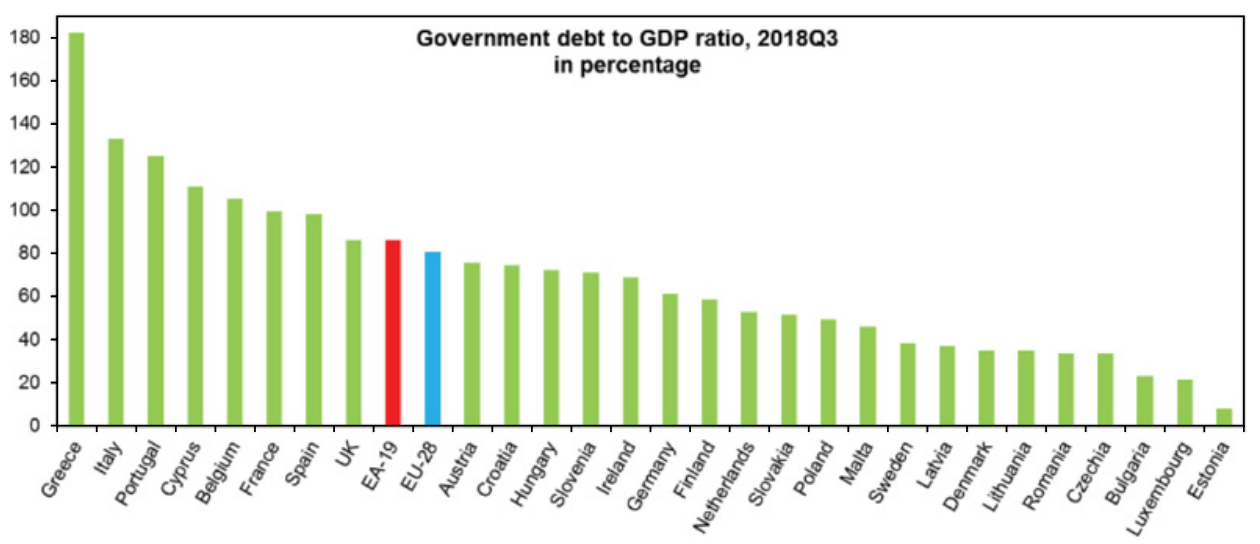

Fig. 1. Government debt to gross domestic product ratio in EU member states during $3^{\text {rd }}$ quarter of 2018 (EA19 - Euro area countries, EU28 - average from all EU member states, source: Eurostat).

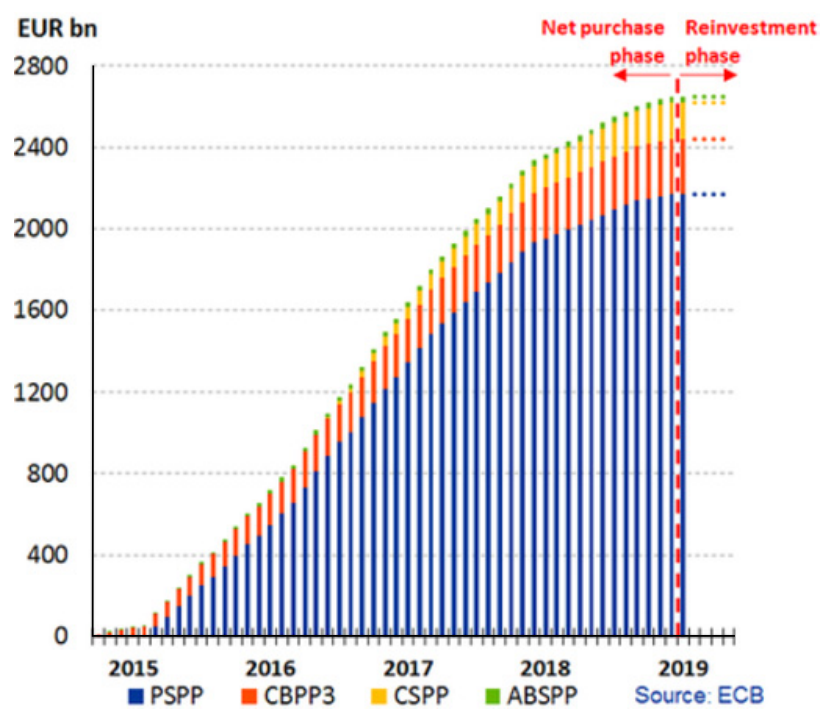

Fig. 2. ECB's APP cumulative net purchases in all programmes in billions per year (source: ECB).

This macroeconomic condition leaves several key risks, including that of targeting unnecessary inflation policies without aiding the increase of the productivity of member state economies [13]. The mentioned economic, legal and court data sufficiently demonstrates the validity of the initial hypothesis. Yet, evaluation of the real-life effects will have mostly delayed results, so for this paper the assumed premise described next is that subsequently inflation will diminish the purchasing power of the euro asymmetrically.

\section{Legal theoretical framework for property right protection}

This paper has shown the basic theoretical models for macroeconomic correlations within monetary policies in the EU. The measurement of monetary policy as a form of legislative action results in a systemic context. For example, the debt level of a member state government as an indicator of overall public spending, fiscal discipline and financial asset 
allocation. Accordingly, for legal research to advance the conditions have to be applied within a theoretical framework of law, i.e., the data has to be included in the research of law by a synthesized transmission mechanism. As the adjective "macro" describes a very large or encompassing scope, the author chose to initiate the use of a macro-juristic theory for the following descriptions of juristic causalities relating to the subjects of this paper.

The legislative actions of monetary policy are intended to impact financial markets, especially to stimulate economic activity and output. As far as can be predicted in individual research samples, larger peak output responses are associated with healthier banking systems and lower government debts, which would mean that the ECB's unconventional legislative measures and their results would tend to go against their goal or legitimate aim [14]. It is noteworthy that this also applies to global concepts of convergence or divergence of economic policies. This is the case with international trade and heavily regulated industries such as banking, because those have several integrated and valuable attributes like attractiveness for foreign investment [15]. So it would be reasonable to assume that convergence with ECB policies would be hindered by the individual economic interests of member states, causing more debate about lessening independence.

For this article, the research limitations lie within the integration challenges of monetary policy and lack of empirical causation, so the proposed macro-juristic theory can at least address the social security interests of the most vulnerable residents such as pensioners, the unemployed etc. Adjusting policies according to pension and other social welfare needs is a traditional legislative action, which means that the member state legislators have already established methods of achieving legitimate aims.

Having regard to the mentioned concerns, the results suggest a legal theory of inflationary proportionality, anticipating that the impact of economic results caused by loss of money's purchasing power on social security and general rights to property is not effectively monitored, if monetary and economic legislative power is not consolidated. Hence, inflationary proportionality would mean that only consolidated economic legislative power can ensure the targeted and proportionate implementation of economic conditions through the use of democratically legitimized power. This means that central banks nowadays establish conventional or unconventional ways of stimulating the economy, yet their decisions, as was shown in the paper's $3^{\text {rd }}$ reference and $3^{\text {rd }}$ section, do not contain any proportionality ex ante evaluation, but solely macroeconomic variability.

However, those were not even the issues at hand in the mentioned court cases of the European Court of Justice. Therefore, results show that currently the proportionality of monetary legislation is not an established practical or even theoretical model of law. Hence, it is suggested to not just consolidate monetary and macroeconomic legislature, but also to use similar constitutionality checkmarks such as the need in a democratic society where the benefits for society outweigh the losses for individuals. According to those criteria the ECB would have to provide expressis verbis descriptions and sound evidence of the need for a specific amount of inflation and also that the methods used will bring the indented consequences. It should be noted that this paper is not intended for evaluating whether the consolidated monetary and economic legislation power should belong to the traditional legislators or to central banks, but based on prima facie data at least in the short-term central banks could have a more competent response to the dynamic needs of economic and social policy.

The author therefore proposes the following theoretical framework for ensuring property right proportionality evaluations in future monetary legislation. By providing short-term 
solutions within the theory of inflationary proportionality, the following financial sector legislative steps can be identified:

1. Ensure social security legislation planning competence for central banks;

2. Introduce periodic review of the empirical impact of inflation at least for social security legislation;

3. Hindering liquidity in the credit institution system if the money is not directed to the business of an active economic sector (value-added sector);

4. Strengthen the fundamental right of natural persons to preserve the value of time consumed for work as a right to property in terms of money's purchasing power.

The following financial sector legislative steps can be identified in the long run:

1. Introduce mandatory training of executive officers when the work concerns the preparation of legislative acts, especially in the financial sector;

2. Provide that the self-assessment of the economic activities of financial sector entities should include the impact of potential operational risks on the stability of public administration, including spending and fiscal discipline.

The mentioned steps are derived from the fact that a sovereign has exclusive constitutional competence to issue and distribute money and there is neither a theoretical nor a practical need to retrieve part of it back as tax or other forms of payments because it then returns only to the starting point. By delegating such competence to a specific institution in a democratically legitimate manner, the legislator separates from this function and relies on the responsible action of the institution, i.e., central bank. However, security requirements can be incorporated to ensure that the most vulnerable people of society are protected from any downsides since monetary policy decisions, especially disputed unconventional measures, are legislative acts, which can be assessed and edited.

\section{Conclusions}

According to the legal and theoretical evaluation, the author states the following:

1. The Treaty on the Functioning of the European Union has created a central, but legally unsophisticated monetary policy mechanism for unconventional decisions by the ECB. It has no attachment to the protection of property value, including purchasing power of money.

2. Property protection within unconventional monetary policies can be achieved by effective use of member state legal practice and experience. For instance, analysis of regional economic conditions was made before the ECB had the exclusive competence for unconventional policies, so those can be continued or increased.

3. The article demonstrates that unconventional monetary decisions create a need for improved legal trust for effectiveness, yet the conventional policy evaluation methods have to be improved accordingly for practical effect.

4. Main results show that property protection generally involves proportional considerations, so a macro-juristic theory is described to limit the unconventional monetary policy outlines for a unified code of conduct related to property protection within every EU member state.

5. Legal scholars have yet to incorporate the main tenets of contemporary monetary policy into legal research. Namely, that the so-called financial crisis was a result of too loose credit policies, which caused a fallout and recession. Since afterwards the way out was decided to be with even more credit and market liquidity, the debate about whether to 
consolidate lawmakers for monetary and economic policy should be had at least on an academic level for either cooperative sovereignty or farsighted convergence.

\section{References}

[1] Consolidated versions of the Treaty on European Union and the Treaty on the Functioning of the European Union. EU Official Journal C 326, 0001-0390, Art. 132 (2012)

[2] Consolidated versions of the Treaty on European Union and the Treaty on the Functioning of the European Union. Official Journal of the European Union, C 326, 0001-0390, Art. 132 (2012)

[3] Decision (EU) 2015/774 of the ECB of 4 March 2015 on a secondary markets public sector asset purchase programme (ECB/2015/10). Official Journal of the European Union L 121/20, Art. 3 (2015)

[4] P. Hartmann, F. Smets, Working Pap. Ser. 2219, 8 (2018). Available from: https://www.ecb.europa.eu/pub/pdf/scpwps/ecb.wp2219.en.pdf? 5e970b4691284694d7545e14a7364791

[5] C.D. Zimmermann, The Concept of Monetary Sovereignty Revisited, European Journal of International Law. (Oxford University Press, 2013) 24, 797-818. Available from: https://doi.org/10.1093/ejil/cht041

[6] J. Habermas, Eur. J. Int. Law 23(2), 335-348 (2012). Available from: https://doi.org/10.1093/ejil/chs019

[7] Charter of Fundamental Rights of the EU, Official J. Eur. Union C 326/391, Art. 17 (2012)

[8] L. Bočs, Property Right Limitations Within the Fiat Monetary System of the European Union. In: 4th International Multidisciplinary Scientific Conference on Social Sciences and Arts, Conference Proceedings. (SGEM Vienna, Book I, Volume I, 2017), 421-427

[9] C. Macchiarelli, M. Monti, Eur. Union, 23 (2018). Available from: http:// Www . europarl . europa. eu/RegData/etudes/IDAN/2018/619017/IPOL_ IDA (2018)619017_EN.pdf

[10] S. Josten, F. Bartholomae, A. Schoenberg. CESifo Forum 17(1), Leibniz-Institut für Wirtschaftsforschung an der Universität München, 72-76 (2016)

[11] Judgment of the European Court of Justice in case C-62/14 Peter Gauweiler et al. v Deutscher Bundestag, Par. 127 (2015)

[12] Judgment of the European Court of Justice in case C-493/17 Heinrich Weiss and Others, Par. 144 (2018)

[13] S.C.W. Eijffinger, L.H. Hoogduin. ECB: Quo Vadis? Intereconomics 53, 170-174 (2018)

[14] A. Elbourne, K. Ji, S. Duijndam, Eur. Forecast. Res. Assoc. Macro-Economy, 24 (2018)

[15] S. Cho, J. Kurtz, Eur. J. Int. Law 29, 169-203 (2018). Available from: https://doi.org/10.1093/ejil/chy011 